\title{
Effects of Angiotensin II on Erythropoietin Production in the Kidney and Liver
}

\author{
Yukiko Yasuoka ${ }^{1}$, Yuichiro Izumi ${ }^{2}{ }^{\circledR}$, Takashi Fukuyama ${ }^{3}$, Hideki Inoue ${ }^{2}$, Tomomi Oshima ${ }^{1}$, Taiga Yamazaki ${ }^{3}{ }^{\circledR}$, \\ Takayuki Uematsu ${ }^{3}{ }^{\circ}$, Noritada Kobayashi ${ }^{3}$, Yoshitaka Shimada ${ }^{4}$, Yasushi Nagaba ${ }^{4} \oplus$, Masashi Mukoyama ${ }^{2}$, \\ Yuichi Sato ${ }^{5}{ }^{\circ}$, Jeff $M$ Sands ${ }^{6}{ }^{\infty}$, Katsumasa Kawahara ${ }^{1}$ and Hiroshi Nonoguchi ${ }^{4, *}$
}

1 Department of Physiology, Kitasato University School of Medicine, 1-15-1 Kitasato, Minami-ku, Sagamihara 252-0374, Kanagawa, Japan; yasuoka@med.kitasato-u.ac.jp (Y.Y.); tomomio@kitasato-u.ac.jp (T.O.); kawahara@kitasato-u.ac.jp (K.K.)

2 Department of Nephrology, Graduate School of Medical Sciences, Kumamoto University, 1-1-1 Honjo, Chuo-ku, Kumamoto 860-8556, Kumamoto, Japan; izumi_yu@kumamoto-u.ac.jp (Y.I.); hideki24@kumamoto-u.ac.jp (H.I.); mmuko@kumamoto-u.ac.jp (M.M.)

3 Division of Biomedical Research, Kitasato University Medical Center, 6-100 Arai, Kitamoto 364-8501, Saitama, Japan; fukuyam@insti.kitasato-u.ac.jp (T.F.); tyamazak@insti.kitasato-u.ac.jp (T.Y.); tuematsu@insti.kitasato-u.ac.jp (T.U.); kenchu@insti.kitasato-u.ac.jp (N.K.)

4 Division of Internal Medicine, Kitasato University Medical Center, 6-100 Arai, Kitamoto 364-8501, Saitama, Japan; yoshi@insti.kitasato-u.ac.jp (Y.S.); nagaba-y@insti.kitasato-u.ac.jp (Y.N.)

5 Department of Molecular Diagnostics, School of Allied Health Sciences, Kitasato University, 1-15-1 Kitasato, Minami-ku, Sagamihara 252-0373, Kanagawa, Japan; yuichi@med.kitasato-u.ac.jp

check for updates

Citation: Yasuoka, Y.; Izumi, Y.; Fukuyama, T.; Inoue, H.; Oshima, T.; Yamazaki, T.; Uematsu, T.; Kobayashi, N.; Shimada, Y.; Nagaba, Y.; et al. Effects of Angiotensin II on Erythropoietin Production in the Kidney and Liver. Molecules 2021, 26, 5399. https://doi.org/10.3390/ molecules26175399

Academic Editor: Hideyuki Takeuchi

Received: 9 August 2021

Accepted: 2 September 2021

Published: 5 September 2021

Publisher's Note: MDPI stays neutral with regard to jurisdictional claims in published maps and institutional affiliations.

Copyright: (c) 2021 by the authors. Licensee MDPI, Basel, Switzerland. This article is an open access article distributed under the terms and conditions of the Creative Commons Attribution (CC BY) license (https:/ / creativecommons.org/licenses/by/ $4.0 /)$.
6 Renal Division, Department of Medicine, Emory University School of Medicine, 1639 Pierce Drive, WMB Room 3313, Atlanta, GA 30322, USA; jeff.sands@emory.edu

* Correspondence: nono@insti.kitasato-u.ac.jp; Tel.: +81-48-593-1212

\begin{abstract}
The kidney is a main site of erythropoietin production in the body. We developed a new method for the detection of Epo protein by deglycosylation-coupled Western blotting. Detection of deglycosylated Epo enables the examination of small changes in Epo production. Using this method, we investigated the effects of angiotensin II (ATII) on Epo production in the kidney. ATII stimulated the plasma Epo concentration; Epo, HIF2 $\alpha$, and PHD2 mRNA expression in nephron segments in the renal cortex and outer medulla; and Epo protein expression in the renal cortex. In situ hybridization and immunohistochemistry revealed that ATII stimulates Epo mRNA and protein expression not only in proximal tubules but also in collecting ducts, especially in intercalated cells. These data support the regulation of Epo production in the kidney by the renin-angiotensin-aldosterone system (RAS).
\end{abstract}

Keywords: erythropoietin; angiotensin II; renin-angiotensin-aldosterone system; deglycosylation; Western blotting; HIF2 $\alpha$; proximal tubules; collecting ducts

\section{Introduction}

Erythropoietin (Epo) stimulates erythrocyte production in the bone marrow [1]. Hypoxia and anemia stimulate Epo production by the kidney [1-4]. Severe hypoxia and severe anemia cause more than a 500-fold increase in the serum Epo concentration [5]. However, such conditions are rare and most people do not experience them during their lives. The serum Epo concentration in normal people is low, and Epo protein expression in control kidneys has been too low to detect [5-8]. We developed a new Western blotting method and found that deglycosylated Epo is an accurate marker of Epo expression [5,9]. Epo protein in the kidney is detected at $34-43 \mathrm{kDa}$, and deglycosylation using PNGase shifts the band to $22 \mathrm{kDa}$. The broad Eoo band is concentrated to a narrow $22 \mathrm{kDa}$ band, which results in an increase in detection sensitivity by 10-100-fold [5,9]. Thus, the detection of small changes in Epo production has become possible. 
The renin-angiotensin-aldosterone system (RAS) regulates renal water and electrolyte excretion to maintain body fluid homeostasis [10,11]. RAS inhibitors cause anemia by reducing Epo production. Kim et al. reported that angiotensin II (ATII) increases Epo production via angiotensin 1 receptor (AT1R)-mediated early growth response-1 (Egr-1) activation in human renal $786-\mathrm{O}$ cells $[12,13]$ Kato et al. reported that transgenic mice having renin and angiotensinogen genes exhibit erythrocytosis and that knockout mice lacking renin and angiotensinogen exhibit anemia [14,15]. The anemia of angiotensinogenknockout mice was rescued by ATII infusion, suggesting that a genetic pathway from angiotensinogen to ATII plays a key role in ATII-induced Epo production. These reports suggest that Epo production is regulated not only by hypoxia or anemia but also by RAS [4,12,14-18]. In our previous reports, we showed that aldosterone stimulates Epo production by the intercalated cells of the collecting ducts [7]. In this report, we examined the effects of ATII on Epo production by the kidney and liver.

\section{Results}

\subsection{Plasma Epo Concentration}

ATII administration increased the plasma Epo concentration from $1.4 \pm 0.2$ to $2.9 \pm 0.3 \mathrm{mIU} / \mathrm{mL}$ (Figure 1a).

2.2. Epo mRNA Expression in the Renal Cortex and Microdissected Proximal Convoluted Tubules (PCT) and Medullary Thick Ascending Limbs (MAL)

ATII stimulated Epo and HIF2 $\alpha$ mRNA expression in the renal cortex by $13.2 \pm 4.7$ and $11.4 \pm 0.6$ times by A1 and A10, respectively $(n=3-4)$ and $9.6 \pm 3.7$ and $8.6 \pm 2.6$ times by A1 and A10, respectively $(n=3-4)$ (Figure $1 \mathrm{~b}, \mathrm{c})$. In microdissected PCT, ATII increased Epo mRNA by $3.4 \pm 0.7$ and $2.4 \pm 0.2$ times by $10^{-9} \mathrm{M}$ and $10^{-6} \mathrm{M}$ ATII, respectively $(n=3)$ and HIF $2 \alpha$ mRNA by $2.0 \pm 0.2$ and $2.3 \pm 0.8$ times by $10^{-9} \mathrm{M}$ and $10^{-6} \mathrm{M}$ ATII, respectively $(n=3)$ (Figure $1 \mathrm{~d}, \mathrm{e})$. ATII also increased Epo mRNA expression in MAL by $4.3 \pm 1.0$ and $6.5 \pm 2.0$ times by $10^{-9} \mathrm{M}$ and $10^{-6} \mathrm{M}$ ATII, respectively $(n=3)$ (Figure $1 \mathrm{f}$ ).

a

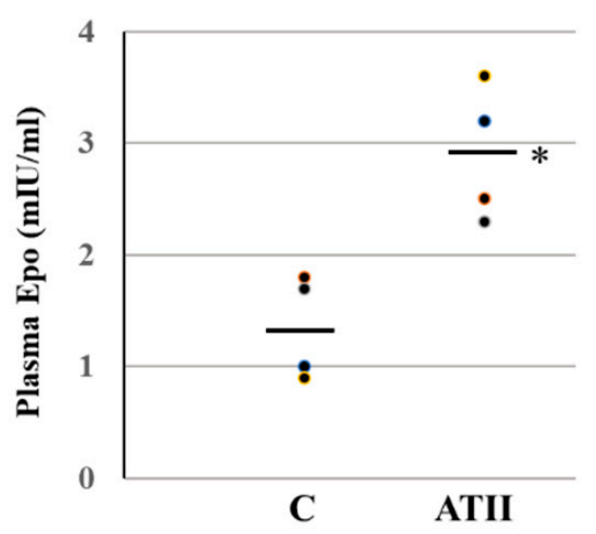

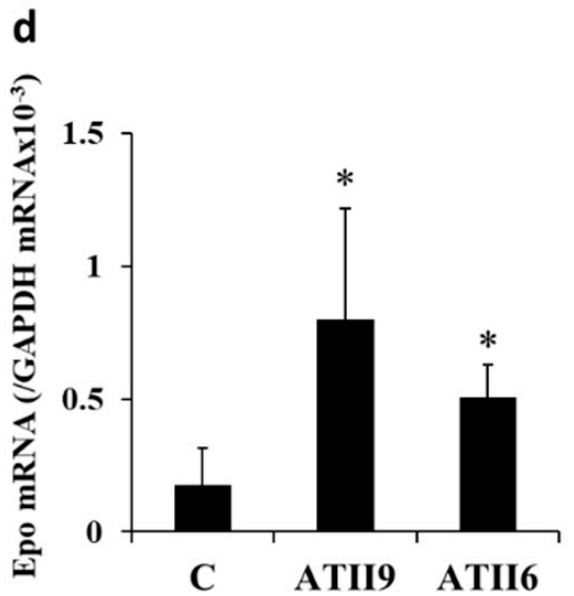

Figure 1. Cont. 

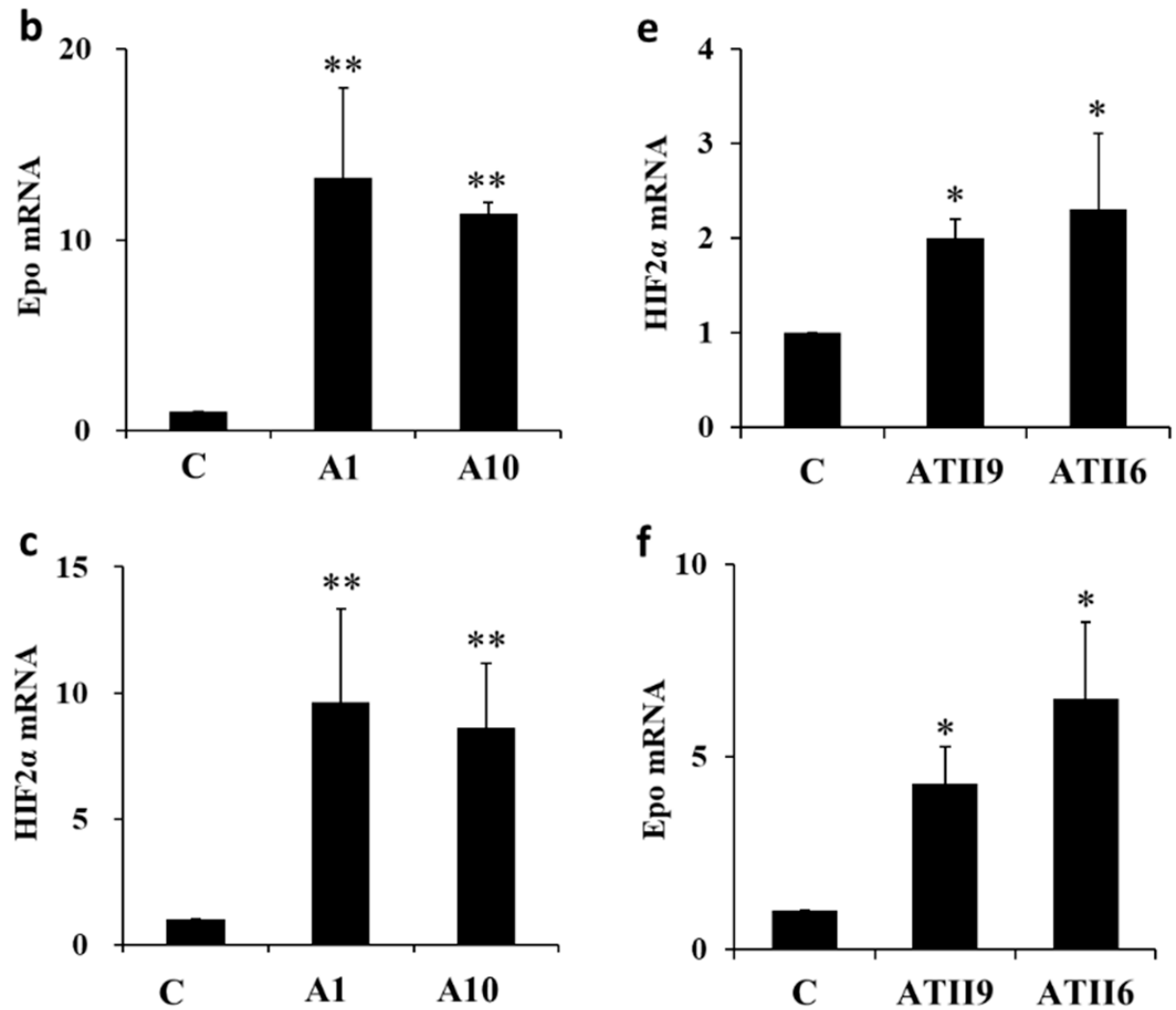

Figure 1. Epo mRNA expression. (a) Plasma Epo concentration in control and ATII-injected rats. ATII significantly increased the plasma Epo concentration from $1.4 \pm 0.2$ to $2.9 \pm 0.3 \mathrm{mIU} / \mathrm{mL}$ $\left({ }^{*} p<0.05\right)$. (b,c) ATII significantly increased Epo mRNA expression in the renal cortex $(13.2 \pm 4.7$ and $11.4 \pm 0.6$ times increase by A1 and A10, respectively) (b), and HIF2 $\alpha$ mRNA expression was also stimulated by ATII (9.6 \pm 3.7 and $8.6 \pm 2.6$ times increase by A1 and A10, respectively) (c). (d-f) In microdissected nephron segments, ATII increased Epo mRNA expression in PCT (d) and MAL (f). HIF1 $\alpha$ mRNA was also increased by ATII in PCT (e). C, control; A1, ATII $1 \mathrm{mg} / \mathrm{kg}$; A10, ATII $10 \mathrm{mg} / \mathrm{kg}$; ATII9, AT2 $10^{-9} \mathrm{M}$; ATII6, ATII $10^{-6} \mathrm{M}$. ${ }^{*} p<0.05,{ }^{* *} p<0.01$ by the $t$-test or a non-parametric analysis using the Kruskal-Wallis test and multiple comparisons by the Dunnett or Shirley-Williams' test.

\subsection{In Situ Hybridization of Epoand the Effects of ATII}

Epo mRNA expression was observed in cortical nephrons under basal conditions, as previously reported [19]. ATII stimulated Epo mRNA expression in PCT, MAL, and cortical and medullary collecting ducts (CCD and OMCD) after $2 \mathrm{~h}$ (Figure 2: 2a, 2d). HIF2 $\alpha$ mRNA expression increased in most nephron segments and peritubular cells of both the cortex and the medulla (Figure 2: 2-4b, 2-4e). PHD2 mRNA expression also increased in MAL, CCD, and OMCD (Figure 2: 3-4c, 3-4f). ATII failed to induce Epo mRNA expression in the peritubular cells of the renal cortex. 


\section{Time after the injection of AT II hr)}

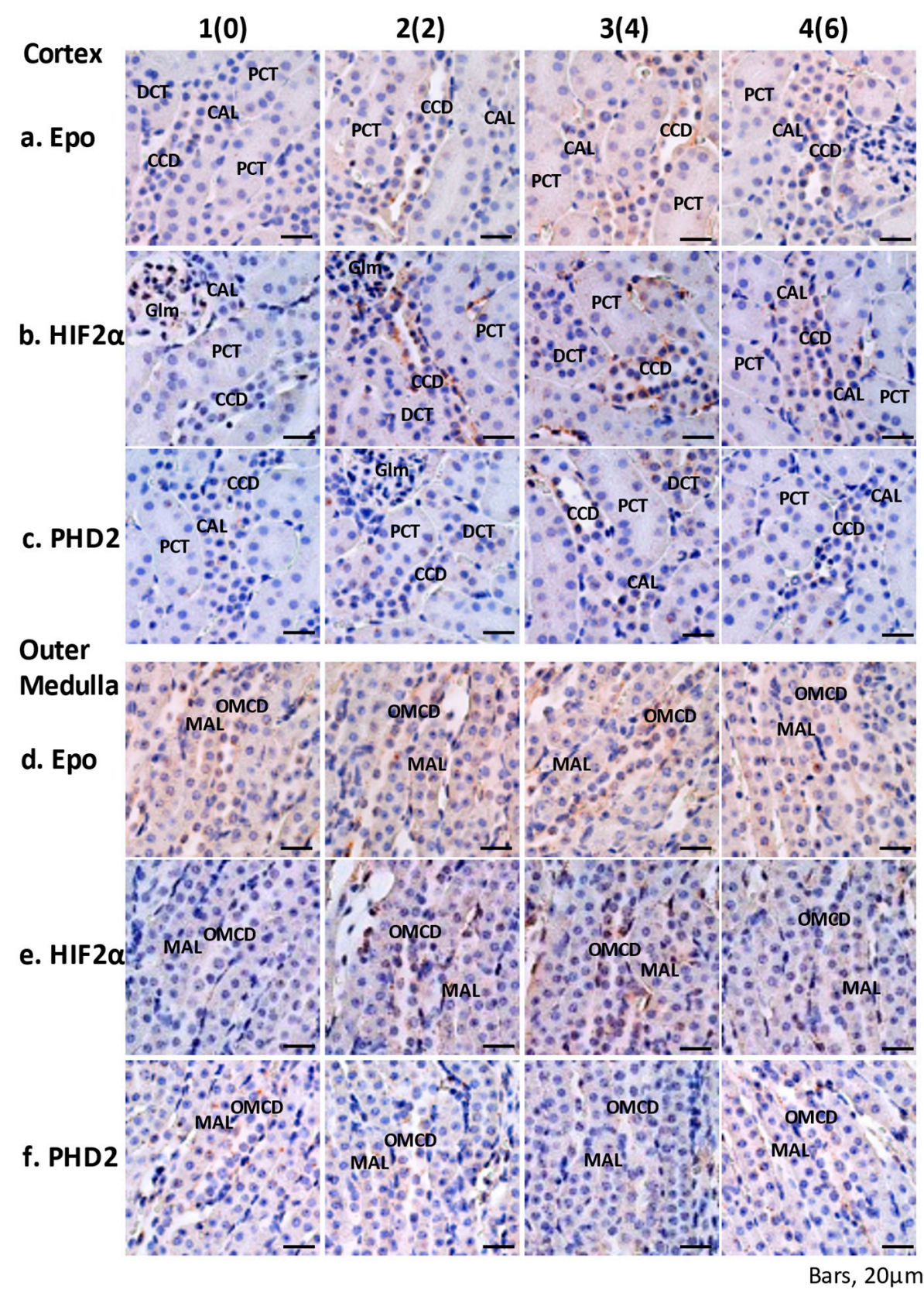

Figure 2. Effects of ATII on Epo mRNA expression evaluated by ISH. In situ hybridization was used to analyze the effects of ATII on Epo, HIF2 $\alpha$, and PHD2 mRNA expression in mouse kidneys. Epo mRNA expression was observed in cortical nephrons under basal conditions (1-a,d). ATII stimulated Epo mRNA expression in PCT, MAL, CCD, and OMCD at 2-6 h (2 4-a,d) and HIF2 $\alpha$ mRNA expression in most nephron segments and peritubular cells of both the cortex and the medulla at 2-6 h (2 4-b,e). In contrast, ATII stimulated PHD2 mRNA expression in MAL, CCD, and OMCD at 4-6 h (3 4-c,f). (a-c) Renal cortex and (d-f) renal outer medulla. The numbers 1, 2, 3, and 4 show $0,2,4$, and $6 \mathrm{~h}$ after the injection of ATII, respectively.

\subsection{Western Blotting Analysis of ATII-Induced Epo Production in the Kidney and Liver}

The effects of fludrocortisone, an aldosterone agonist, were examined using deglycosylation-coupled Western blotting. The band of deglycosylated Epo at $22 \mathrm{kDa}$ was observed in control rats (C2, C4, and C6 in Figure 3a right side), showing that Epo is produced in control rats. Fludrocortisone significantly stimulated the expression of deglycosylated Epo at 2 and $4 \mathrm{~h}$ after injection. The expression became equal to that in control rats after $6 \mathrm{~h}$. Next, the 
effect of ATII on Epo expression was examined. The effect of ATII on Epo production was larger in the renal cortex than in the renal outer medulla (Figure 3b). The effect of ATII on Epo production was not observed in the renal inner medulla (data not shown). ATII dosedependently increased Epo protein expression (Figure 3c). ATII increased deglycosylated Epo production in the renal cortex by $1.6 \pm 0.2$ and $3.4 \pm 0.3$ times by 1 and $10 \mathrm{mg} / \mathrm{kg}$, respectively $(n=6-8)$. In contrast, Epo production was not seen in the liver, even after the administration of ATII (Figure 3d).

a
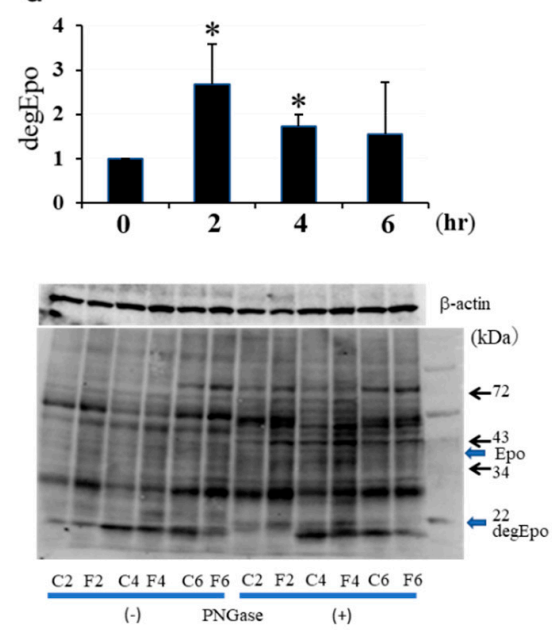

c

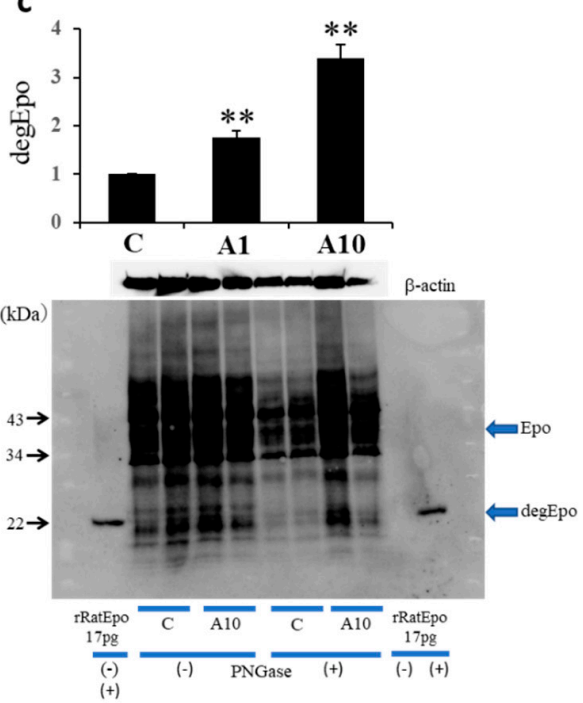

b
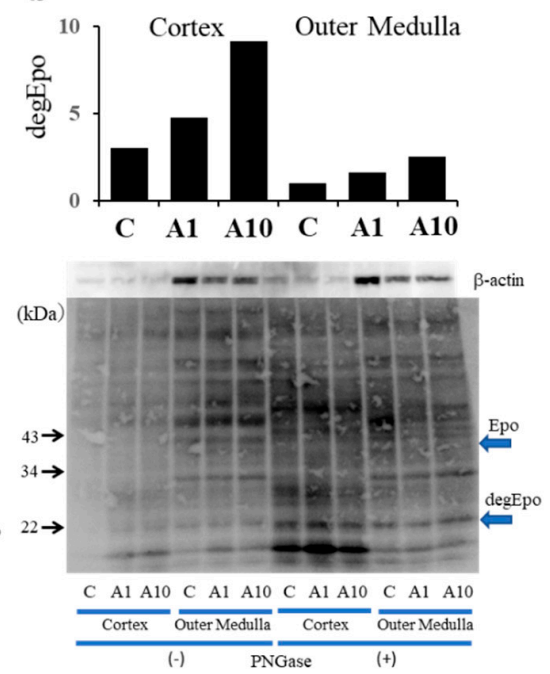

d

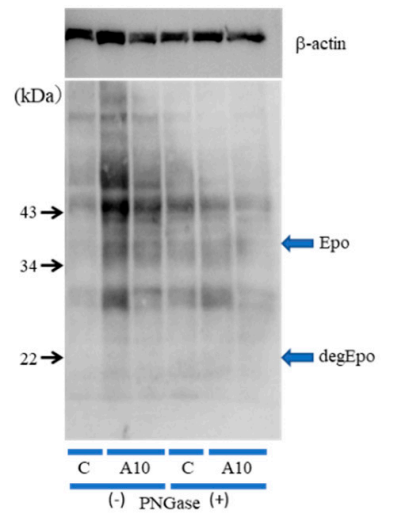

Figure 3. Effects of fludrocortisone and ATII on Epo protein expression in the kidney and liver. (a) Effects of fludrocortisone on Epo production in the kidney. Fludrocortisone increased deglycosylated Epo protein expression at 2 and $4 \mathrm{~h}$ after the injection. The levels returned to basal values after 6 h. (b) ATII dose-dependently increased deglycosylated Epo protein expression in the renal cortex and outer medulla. The effects were larger in the renal cortex than in the renal outer medulla. (c) ATII increased deglycosylated Epo production in the renal cortex by 1.6- and 3.4-fold by 1 and $10 \mathrm{mg} / \mathrm{kg}$, respectively. (d) In contrast, deglycosylated Epo production was not observed in control and ATII-injected livers. Recombinant rat Epo is shown as the control in Figure 3c. Glycosylated Epo and deglycosylated rat Epo were used in lane 1. Glycosylated Epo and deglycosylated Epo were used in lanes 11 and 12 , respectively. ${ }^{*} p<0.05,{ }^{* *} p<0.01$ by a non-parametric analysis using the Kruskal-Wallis test and multiple comparisons by the Shirley-Williams' test. 


\subsection{Immunohistochemistry of Epo Production by the Kidney}

By IHC of mice, under basal conditions, Epo staining was found from the proximal tubules to the collecting ducts (proximal tubules $<$ thick ascending limbs $<$ collecting ducts) (Figure 4). ATII increased Epo production in PCT, MAL, CCD, and OMCD after 4-6 h (Figure 4; 3a, 3b, 3c, 4a, 4b and 4c). In the collecting duct, Epo expression was detected only in the type A intercalated cells, as previously reported (brown cells in Figure $4 ; 3 \mathrm{c}$ and $4 \mathrm{c})[7,19]$. Epo staining was not detected in peritubular cells under these conditions.

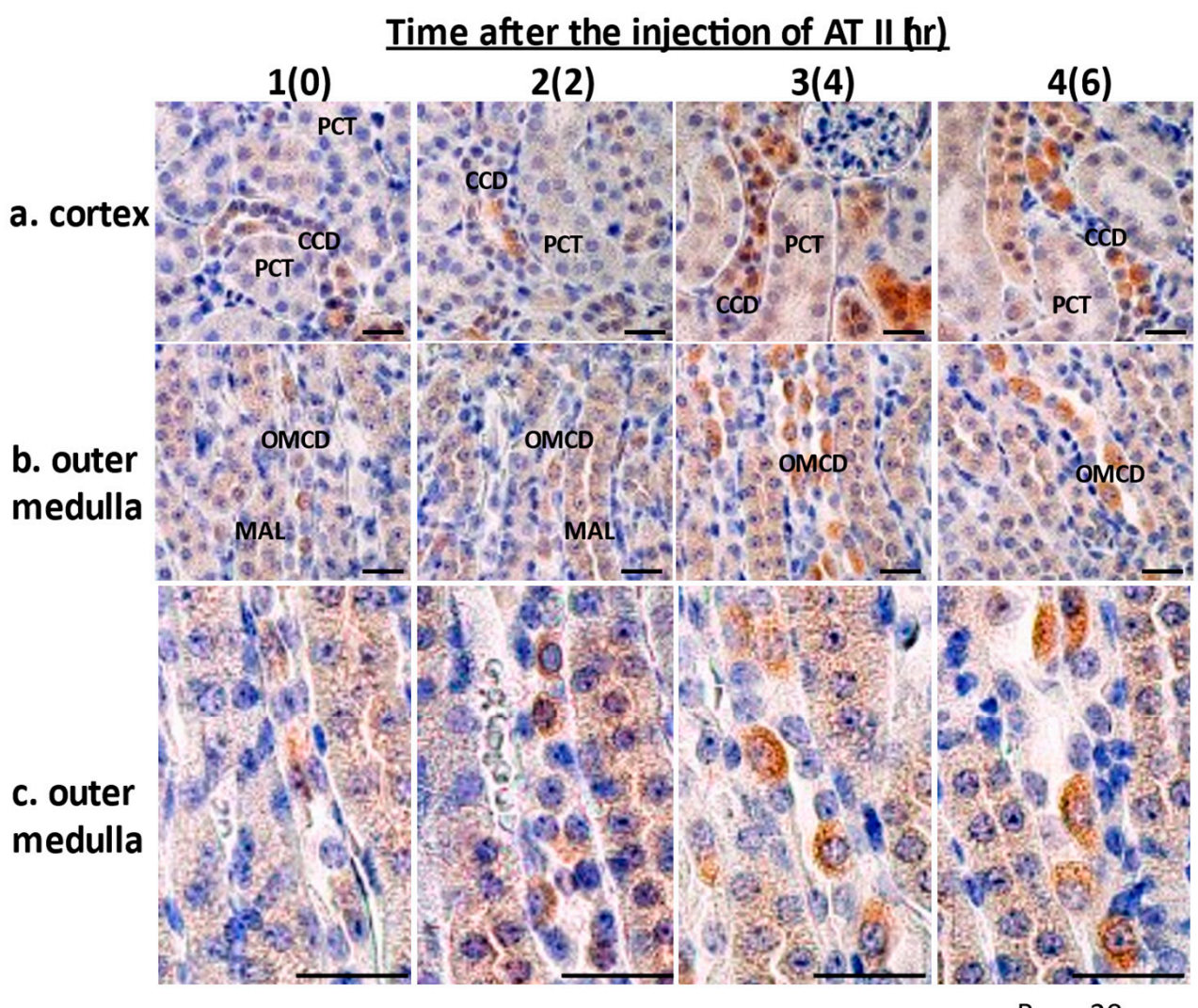

Bars, $20 \mu \mathrm{m}$

Figure 4. Immunohistochemical study of the effects of ATII on Epo production by the kidney. Under basal conditions, Epo staining was found from the proximal tubules to the collecting ducts (proximal tubules < thick ascending limbs < collecting ducts) (1-a-c). ATII increased Epo production in MAL, CCD, and OMCD (3 4-a-c), particularly in the type A intercalated cells, after 4-6 h (brown cells in $3 \sim 4-\mathbf{a}-\mathbf{c})$. The renal outer medulla is shown at a different magnification. The numbers $1,2,3$, and 4 show $0,2,4$, and $6 \mathrm{~h}$ after the injection of ATII, respectively.

\section{Discussion}

The detection of Epo by Western blotting was difficult until our finding of a deglycosylation-coupled assay $[5,7,9,20-26]$. In severe hypoxia and anemia, the production of Epo is stimulated to a high level and the detection of Epo is easy [2-5]. However, such conditions are rare in vivo. We found that Epo is produced by the kidney even under control conditions. The detection of Epo in the control kidney is difficult, even by our Western blotting. Deglycosylation of Epo by PNGase increases the band intensity of Epo at $22 \mathrm{kDa}$, making it possible to detect lower levels of Epo. Using this method, we investigated the effects of fludrocortisone and ATII on Epo production.

ATII increased Epo mRNA expression in the renal cortex. Next, we examined the effects of ATII on Epo mRNA expression in microdissected PCT and MAL. ATII increased Epo mRNA expression in PCT and MAL. We also examined the effects of ATII by in situ hybridization (ISH). ISH revealed that ATII increases Epo mRNA expression not only in 
proximal tubules but also in distal tubules. Furthermore, we investigated Epo protein expression by Western blotting. Deglycosylation-coupled Western blotting was used in this study. The results show that ATII dose-dependently increases Epo protein expression in the kidney but not in the liver. The plasma Epo concentration increased by $2-3$-fold, which is compatible with previous reports $[4,6,8,12]$. This level of Epo production in blood cannot be measured by Western blotting. However, deglycosylation-coupled Western blotting made the detection possible. ATII significantly increased Epo protein expression in the kidney. Immunohistochemistry also showed that ATII increases Epo protein expression in both proximal and distal tubules. The effect of ATII is identical to that of fludrocortisone in the intercalated cells of the collecting ducts [7]. Our study is the first one that shows the intrarenal localization of ATII-induced Epo production by ISH and IHC.

ATII also increased HIF2 mRNA expression in the renal cortex and proximal convoluted tubules, showing that the increase in Epo production by ATII is caused by the stimulation of HIF2, the same as aldosterone [7]. Our study indicates that Epo production by the kidney is regulated by the renin-angiotensin-aldosterone system. The role of ATII on Epo production in the kidney has been suggested [4,12,16-18]. Jelkmann suggested indirect effects of angiotensin II as a growth factor for myeloid erythrocytic progenitors [4]. Kim et al. clearly reported that angiotensin II stimulates Epo production via AT1R-mediated Egr-1 activation by p21Ras-mitogen-activated protein kinase/extracellular signal-regulated kinase (ERK) kinase-ERK/2 in human renal 786-O cells [12,13]. The role of a genetic pathway from angiotensinogen to ATII was examined by Kato et al. [14,15]. They showed that transgenic mice having renin and angiotensinogen genes exhibit erythrocytosis. They also reported that knockout mice lacking renin and angiotensinogen exhibit anemia that was rescued by ATII infusion, suggesting that a genetic pathway from angiotensinogen to ATII plays a key role in ATII-induced Epo production. The mechanisms of Epo production under severe hypoxic and basal conditions may be different, but some steps such as the stimulation of HIF2 could be the same. The ability to produce Epo would be different between renal interstitial cells and nephrons. The detection of HIF2 by Western blotting was not successful in this study; we could not detect the HIF2 band at around 115 $\mathrm{kDa}$, even by the use of sc-46691, sc-13596, Ab8365, and NB100-122.

\section{Materials and Methods}

\subsection{Materials and Animals}

Male Sprague-Dawley rats (Japan SLC, Hamamatsu, Japan) and C57BL/6J mice (Charles River Japan, Yokohama, Japan) were used. Rats were given 1 or $10 \mathrm{mg} / \mathrm{kg}$ of ATII (A1 and A10, respectively), and mice were given $5 \mathrm{mg} / \mathrm{kg}$ of ATII by intraperitoneal injection. The control group was injected with saline. After $4 \mathrm{~h}$, rats were injected with a mixed anesthetic $(0.3 \mathrm{mg} / \mathrm{kg}$ of medetomidine, $4.0 \mathrm{mg} / \mathrm{kg}$ of midazolam, and $5.0 \mathrm{mg} / \mathrm{kg}$ of butorphanol), and blood was taken from the abdominal aorta. The kidneys and liver were dissected after perfusing $20 \mathrm{~mL}$ of PBS into the abdominal aorta. In some experiments, kidney slices were incubated in collagenase (type 1, C-0130; Sigma-Aldrich, Burlington, NJ, USA) and ribonucleoside vanadyl complexes (R-3380; Sigma-Aldrich) for 20 min and PCT and MAL were microdissected, as described previously [7]. Microdissected PCT or MAL were incubated with ATII or the vehicle for $2 \mathrm{~h}$ at $37^{\circ} \mathrm{C}$. Mice were anaesthetized with $1.5 \%$ isoflurane in $30 \% \mathrm{O}_{2}$ (a mixture of $100 \% \mathrm{O}_{2}$ and air) after 2,4 , and $6 \mathrm{~h}$. The kidneys were quickly removed and cut longitudinally. The main kidney pieces were fixed by immersion in ice-cold $4 \%$ paraformaldehyde/0.1 M phosphate buffer overnight and processed in paraffin for histological analysis.

Our protocols were checked and approved by the Institutional Ethics Committee of the Kitasato University Medical Center (2018032, 2019029) and the Kitasato University School of Medicine (2019-141). 


\subsection{Real-Time PCR}

RNA was extracted from the kidney, liver and microdissected PCT or MAL using Qiacube and the RNeasy Mini Kit (74106; Qiagen, Venlo, The Netherlands), as described previously [5]. cDNA was synthesized using a Takara PrimeScript II 1st strand cDNA Synthesis Kit (6210; Takara, Otsu, Japan). Real-time PCR was performed using probes from Applied Biosystems (GAPDH Rn01775763_g1, Epo Rn00667869_m1, HIF2 Rn00576515_m1, HIF1a Rn01472831_m1, PHD2 Rn00710295_m1; Waltham, MA, USA) and Premix Ex Taq (RP39LR; Takara). mRNA expression in control and ATII rats was compared using $\Delta \Delta C T$.

\subsection{In Situ Hybridization}

ISH was performed, as described previously [5,27]. In brief, total RNA from the mouse kidneys (636612; BD Bioscieces Clontech) was reverse-transcribed with an RNA PCR kit (AMV), ver. 3.0 (RR019; Takara), and the cRNA probe for Epo (GenBank accession no. NM_007942), HIF2 $\alpha$ (GenBank accession no. NM_010137), or PHD2 (GenBank accession no. NM_053207) was generated with T7 promoter region-tailed PCR primers. The hybridized sections were successively treated with $0.1 \%$ avidin, $0.01 \%$ biotin solution, $0.5 \%$ casein/TBS, horseradish peroxidase (HRP)-conjugated sheep anti-DIG F $\left(\mathrm{ab}^{\prime}\right)$ fragment antibody (11207733910; Roche Diagnostics, Basel, Switzerland), biotinylated tyramide solution, and HRP-conjugated streptavidin (P0397; DakoCytomation, Glostrup, Denmark). Sections were stained using the DAB liquid system (BSB 0016; Bio SB, Santa Barbara, CA, USA) and Mayer's hematoxylin (30002; Muto Pure Chemicals, Tokyo, Japan).

\subsection{Immunohistochemistry}

Kidney sections were immuno-stained, as described previously $[7,28]$. In brief, the sections were blocked with $5 \%$ normal goat serum and reacted with rabbit polyclonal anti-human Epo antibody (sc-7956, 1:50; Santa Cruz Biotechnology, Santa Cruz, CA, USA), followed by Histofine Simple Stain MAX-PO (414341F; Nichirei Bioscience, Tokyo, Japan). Sections were stained using the DAB liquid system and counterstained with Mayer's hematoxylin.

Images were obtained using an optical microscope (Axioplan 2; Carl Zeiss, oberkochen, Germany) with a digital camera (AxioCam MRc5; Carl Zeiss). Captured images were analyzed using an image analysis system (AxioVision Rel. 4.6; Carl Zeiss).

\subsection{Western Blotting Analysis with Deglycosylation}

Western blotting analysis was performed, as described previously [4,6,7]. Protein was collected from the renal cortex and liver using CelLytic MT (C-3228; Sigma-Aldrich) and used for Western blotting. Kidney and liver samples were deglycosylated using Nglycosidase F (PNGase, 4450; Takara, as described previously. In brief, $1 \mu \mathrm{L}$ of $10 \%$ SDS was added to $10 \mu \mathrm{L}$ of kidney or liver samples and boiled for $3 \mathrm{~min}$. Then, $11 \mu \mathrm{L}$ of $2 \times$ stabilizing buffer was added and the samples were vortexed. After the addition of 1-2 $\mu \mathrm{L}$ of PBS or PNGase, the samples were incubated in a water bath for $20 \mathrm{~h}$ at $37^{\circ} \mathrm{C}$. After incubation, the samples were spun down and the supernatant was collected and used for SDS-PAGE (10-20\% gradient gel; Cosmo Bio No. 414893, Tokyo, Japan). The $2 \times$ stabilizing buffer contained $125 \mathrm{mM}$ Tris- $\mathrm{HCl}$ (pH 8.6), $48 \mathrm{mM}$ EDTA, $4 \%$ Nonidet P-40, and 8\% 2-mercaptoethanol. Recombinant human Epo (rhEpo, 587102; BioLegend, San Diego, CA, USA) was used as a positive control. After SDS-PAGE, proteins were transferred to a PVDF membrane (Immobilon-P; IPVH00010; Merck Millipore, Burlington, NJ, USA) with $120 \mathrm{~mA}$ for $60-90 \mathrm{~min}$. The membrane was blocked with 5\% skim milk (Morinaga, Japan) for $60 \mathrm{~min}$ and incubated with the antibody against Epo (sc-5290, 1:500; Santa Cruz Biotechnology) for $60 \mathrm{~min}$ at room temperature. After washing, the membrane was incubated with a secondary antibody (goat anti-mouse IgG (H + L); 115-035-166, 1:5000; Jackson Immuno Research Laboratories, West Grove, PA, USA) for $60 \mathrm{~min}$. Bands were visualized by the ECL Select Western Blotting Detection System (RPN2235; GE Healthcare Bio-Science AB, Chicago, IL, USA) and LAS 4000 (Fujifilm, Tokyo, Japan). 


\subsection{Plasma Epo Concentration Measurements}

Plasma was collected from control and ATII-treated rats at $4 \mathrm{~h}$ after peritoneal injection. Plasma Epo concentrations were measured by CLEIA (SRL, Tokyo, Japan) using Access Epo by Beckman Coulter (Brea, CA, USA).

\subsection{Statistical Analyses}

Data are expressed as the mean \pm SEM. Statistical significance was performed using Excel Statistics (BellCurve, Tokyo, Japan). Statistical significance was analyzed using a $t$-test or a non-parametric analysis using the Kruskal-Wallis test and multiple comparisons by the Shirley-Williams' test. $p$-Values $<0.05$ were considered statistically significant.

\section{Conclusions}

In conclusion, our study shows that ATII increases Epo mRNA and protein expression in proximal and distal renal tubules. Combined with our previous studies, Epo production by the kidney under basal conditions is regulated by the renin-angiotensin-aldosterone system.

Author Contributions: Conceptualization, Y.Y. and H.N.; methodology, Y.I. and T.F.; software, Y.S. (Yoshitaka Shimada) and H.N.; validation, Y.I., J.M.S., Y.Y. and K.K.; formal analysis, Y.Y. and H.N.; investigation, Y.Y., H.I., T.O. and H.N.; resources, Y.Y. and T.O.; data curation, T.Y., T.U., N.K. and Y.N.; writing-original draft preparation, H.N.; writing-review and editing, Y.Y. and J.M.S.; visualization, Y.Y. and Y.S. (Yuichi Sato); supervision, M.M., J.M.S. and K.K.; project administration, H.N.; funding acquisition, Y.Y., Y.I., T.F. and H.N. All authors have read and agreed to the published version of the manuscript.

Funding: This research was funded by a Grant-in Aid for Scientific Research from the Ministry of Education, Culture, Sports, Sciences and Technology of Japan (16K09654 (H.N.), 16K08505 (Y.Y.), 18K08247 (Y.I.), and 19K09226 (T.F.)) and by a grant from the Kitasato University Medical Center (H25-003 (T.F.) and H24-011 (H.N.)).

Institutional Review Board Statement: The study was conducted according to the guidelines of the Declaration of Helsinki and approved by the Institutional Ethics Committee of the Kitasato University Medical Center (protocol codes 2018032 (date of approval 22 October 2018) and 2019029 (date of approval 16 January 2021)) and the Kitasato University School of Medicine (protocol code 2019141 (date of approval 2 August 2019)).

Informed Consent Statement: Not applicable for studies not involving humans.

Data Availability Statement: The data presented in this study are openly available.

Conflicts of Interest: The authors declare no conflict of interest.

Sample Availability: Samples of the compounds are available from the authors.

\section{References}

1. Ebert, B.L.; Bunn, H.F. Regulation of the erythropoietin gene. Blood 1999, 94, 1864-1877. [CrossRef] [PubMed]

2. Haase, V.H. Regulation of erythropoiesis by hypoxia-inducible factors. Blood Rev. 2013, 27, 41-53. [CrossRef] [PubMed]

3. Koury, M.J.; Haase, V.H. Anaemia in kidney disease: Harnessing hypoxia responses for therapy. Nat. Rev. Nephrol. 2015, 11, 394-410. [CrossRef] [PubMed]

4. Jelkmann, W. Regulation of erythropoietin production. J. Physiol. 2011, 589, 1251-1258. [CrossRef] [PubMed]

5. Yasuoka, Y.; Fukuyama, T.; Izumi, Y.; Nakayama, Y.; Inoue, H.; Yanagita, K.; Oshima, T.; Yamazaki, T.; Uematsu, T.; Kobayashi, N.; et al. Erythropoietin production by the kidney and the liver in response to severe hypoxia evaluated by Western blotting with deglycosylation. Physiol. Rep. 2020, 8, 14485. [CrossRef] [PubMed]

6. Li, L.H.; Chiu, Y.H.; Meng, C.; Kao, W.F.; How, C.K. Effects of 100-km ultramarathon on erythropoietin variation in runners with hepatitis B virus carrier. Chin. J. Physiol. 2021, 64, 125-128.

7. Yasuoka, Y.; Izumi, Y.; Nagai, T.; Fukuyama, T.; Nakayama, Y.; Inoue, H.; Horikawa, K.; Kimura, M.; Nanami, M.; Yanagita, K.; et al. Fludrocortisone stimulates erythropoietin production in the intercalated cells of the collecting ducts. Biochem. Biophys. Res. Commun. 2018, 503, 3121-3127. [CrossRef]

8. Gossmann, J.; Burkhardt, R.; Harder, S.; Lenz, T.; Sedlmeyer, A.; Klinkhardt, U.; Helmut, G.; Scheuermann, E.H. Angiotensin II infusion increases plasma erythropoietin levels via an angiotensin II type 1 receptor-dependent pathway. Kidney Int. 2001, 60, 83-86. [CrossRef] 
9. Yasuoka, Y.; Fukuyama, T.; Izumi, Y.; Yamashita, T.; Nakayama, Y.; Inoue, H.; Yanagita, K.; Oshima, T.; Yamazaki, T.; Uematsu, T.; et al. Differentiation of endogenous erythropoietin and exogenous ESAs by Western blotting. Heliyon 2020, 6, e05389. [CrossRef]

10. Pham, T.D.; Verlander, J.W.; Wang, Y.; Romero, C.A.; Yue, Q.; Chen, C.; Thumova, M.; Eaton, D.C.; Lazo-Fernandez, Y.; Wall, S.M. Aldosterone regulates pendrin and epithelial sodium channel activity through intercalated cell mineralocorticoid receptordependent and -independent mechanisms over a wide range in serum potassium. J. Am. Soc. Nephrol. 2020, 31, 483-499. [CrossRef] [PubMed]

11. Yamazaki, O.; Ishizawa, K.; Hirohama, D.; Fujita, T.; Shibata, S. Electrolyte transport in the renal collecting duct and its regulation by the renin-angiotensin-aldosterone system. Clin. Sci. (Lond.) 2019, 133, 75-82. [CrossRef]

12. Kim, Y.C.; Mungunsukh, O.; McCart, E.A.; Roehrich, P.J.; Yee, D.K.; Day, R.M. Mechanism of erythropoietin regulation by angiotensin II. Mol. Pharmacol. 2014, 85, 898-908. [CrossRef] [PubMed]

13. Kim, Y.C.; Mungunsukh, O.; Day, R.M. Erythropoietin regulation by angiotensin II. Vitam. Horm. 2017, 105, 57-77. [PubMed]

14. Kato, H.; Ishida, J.; Imagawa, S.; Saito, T.; Suzuki, N.; Matsuoka, T.; Sugaya, T.; Tanimoto, K.; Yokoo, T.; Ohneda, O.; et al. Enhanced erythropoiesis mediated by activation of the renin-angiotensin system via angiotensin II type 1a receptor. Faseb. J. 2005, 19, 2023-2025. [CrossRef] [PubMed]

15. Kato, H.; Ishida, J.; Matsusaka, T.; Ishimaru, T.; Tanimoto, K.; Sugiyama, F.; Yagami, K.; Nangaku, M.; Fukamizu, A. Erythropoiesis and blood pressure are regulated via at1 receptor by distinctive pathways. PLoS ONE 2015, 10, e0129484. [CrossRef] [PubMed]

16. Cole, J.; Ertoy, D.; Lin, H.; Sutliff, R.L.; Ezan, E.; Guyene, T.T.; Capecchi, M.; Corvol, P.; Bernstein, K.E. Lack of angiotensin II-facilitated erythropoiesis causes anemia in angiotensin-converting enzyme-deficient mice. J. Clin. Investig. 2000, 106, 1391-1398. [CrossRef] [PubMed]

17. Kamper, A.L.; Nielsen, O.J. Effect of enalapril on haemoglobin and serum erythropoietin in patients with chronic nephropathy. Scand. J. Clin. Lab. Investig. 1990, 50, 611-618. [CrossRef] [PubMed]

18. Pratt, M.C.; Lewis-Barned, N.J.; Walker, R.J.; Bailey, R.R.; Shand, B.I.; Livesey, J. Effect of angiotensin converting enzyme inhibitors on erythropoietin concentrations in healthy volunteers. Br. J. Clin. Pharmacol. 1992, 34, 363-365. [CrossRef] [PubMed]

19. Nagai, T.; Yasuoka, Y.; Izumi, Y.; Horikawa, K.; Kimura, M.; Nakayama, Y.; Uematsu, T.; Fukuyama, T.; Yamazaki, T.; Kohda, Y.; et al. Reevaluation of erythropoietin production by the nephron. Biochem. Biophys. Res. Commun. 2014, 449, 222-228. [CrossRef] [PubMed]

20. WADA Science/EPO Working Group. Harmonization of Analysis and Reporting of Erythropoietin (EPO) and Other Epo-Receptor Agonists (ESAs) by Polyacrylamaide Gel Electrophoresis (PAGE) Analytical Methods. (TD2021EPO). 2021. Available online: https:/ / www.wada-ama.org/sites/default/files/resources/files/td2021epo_final_eng_v_2.0.pdf (accessed on 1 September 2021).

21. Higuchi, M.; Oh-eda, M.; Kuboniwa, H.; Tomonoh, K.; Shimonaka, Y.; Ochi, N. Role of sugar chains in the expression of the biological activity of human erythropoietin. J. Biol. Chem. 1992, 267, 7703-7709. [CrossRef]

22. Kodama, D.; Nishimiya, D.; Iwata, K.; Yamaguchi, K.; Yoshida, K.; Kawabe, Y.; Motono, M.; Watanabe, H.; Yamashita, T.; Nishijima, K.; et al. Production of human erythropoietin by chimeric chickens. Biochem. Biophys. Res. Commun. 2008, 367, 834-839. [CrossRef] [PubMed]

23. Lasne, F.; de Ceaurriz, J. Recombinant erythropoietin in urine. Nature 2000, 405, 635. [CrossRef] [PubMed]

24. Lasne, F.; Thioulouse, J.; Martin, L.; de Ceaurriz, J. Detection of recombinant human erythropoietin in urine for doping analysis: Interpretation of isoelectric profiles by discriminant analysis. Electrophoresis 2007, 28, 1875-1881. [CrossRef] [PubMed]

25. Reichel, C. SARCOSYL-PAGE: A new electrophoretic method for the separation and immunological detection of PEGylated proteins. Methods Mol. Biol. 2012, 869, 65-79.

26. Yamaguchi, K.; Akai, K.; Kawanishi, G.; Ueda, M.; Masuda, S.; Sasaki, R. Effects of site-directed removal of N-glycosylation sites in human erythropoietin on its production and biological properties. J. Biol. Chem. 1991, 266, 20434-20439. [CrossRef]

27. Yasuoka, Y.; Sato, Y.; Healy, J.M.; Nonoguchi, H.; Kawahara, K. pH-sensitive expression of calcium-sensing receptor (CaSR) in type-B intercalated cells of the cortical collecting ducts (CCD) in mouse kidney. Clin. Exp. Nephrol. 2015, 19, 771-782. [CrossRef]

28. Kobayashi, M.; Yasuoka, Y.; Sato, Y.; Zhou, M.; Abe, H.; Kawahara, K.; Okamoto, H. Upregulation of calbindin D28k in the late distal tubules in the potassium-loaded adrenalectomized mouse kidney. Clin. Exp. Nephrol. 2011, 15, 355-362. [CrossRef] 